\title{
Place Attachment in Land Use Changes: A Phenomenological Investigation in Residents' Lived Experiences with a Renewable Energy Project Deployment
}

\author{
Samiha Mjahed Hammami *(D) and Heyam Abdulrahman Al Moosa
}

check for

updates

Citation: Mjahed Hammami, S.; Abdulrahman Al Moosa, H. Place Attachment in Land Use Changes: A Phenomenological Investigation in Residents' Lived Experiences with a Renewable Energy Project Deployment. Sustainability 2021, 13, 8856. https://doi.org/10.3390/ su13168856

Academic Editor: Seoyong Kim

Received: 31 May 2021

Accepted: 28 July 2021

Published: 8 August 2021

Publisher's Note: MDPI stays neutral with regard to jurisdictional claims in published maps and institutional affiliations.

Copyright: (C) 2021 by the authors. Licensee MDPI, Basel, Switzerland. This article is an open access article distributed under the terms and conditions of the Creative Commons Attribution (CC BY) license (https:// creativecommons.org/licenses/by/ $4.0 /)$
Department of Marketing, College of Business Administration, King Saud University, Riyadh 4545, Saudi Arabia healmousa@ksu.edu.sa

* Correspondence: smjahed@ksu.edu.sa

\begin{abstract}
Despite growing interest in issues of place attachment and land use changes, scholars of renewable energy have tended to overlook the ways that people-place relations affect local acceptance/opposition of renewable energy projects. We address this gap drawing on the concept of customer experience to capture the meaning of place attachment in a specific context of climate change adaptation (e.g., proposals to site large-scale low-carbon energy technologies such as wind farms) and deepening understanding of the role of place attachment in shaping community responses to the local siting of renewable energy technologies. This research adopts a phenomenological approach that focuses on exploring the residents' experiences with the local place where they live (a village in Northeast Tunisia) as well as the meanings they attribute to the project. Results show that according to the evaluation of change, whether the renewable energy project enhances or disrupts the different aspects of place experience, residents will exhibit respectively either positive or negative emotions and attitudes and will take action accordingly either by supporting or protesting the project.
\end{abstract}

Keywords: place attachment; renewable energy; wind energy; community acceptance

\section{Introduction}

In order to mitigate climate change, many countries are fostering investment in lowcarbon energy technologies (e.g., wind farms), which is consistent with the Intergovernmental Panel on Climate Change (IPCC) [1] call for energy transitions. Public acceptance of renewable energy developments represents significant challenges for policy makers.

Although public opinion polls were consistently revealing widespread public support for renewable energy technologies, in reality, local opposition halts project developments [2] This was commonly explained by the "Not In My Backyard" NIMBY phenomenon defined as the attitude of people who oppose the siting of a facility in their neighborhood but not somewhere else [3-5].

Although widely used, researchers increasingly question the relevance of this theory and rejected it as a pejorative and too simplistic explanation for opposition representing people as selfish, irrational, and ignorant. In recent years, researchers recognize and advocate for positioning energy subjects beyond NIMBYism. They suggest useful alternatives of understanding community responses to renewable energy technologies. One pathway considers different socio-psychological factors such as developer trust (e.g., [6]), perceived procedural justice in community renewable energy development (the perceived fairness of planning and siting processes such as local participation, community ownership, local stakeholder engagement, decision-making power and transparency [7]), distributive justice (i.e., perceived benefits and costs for residents living close to turbines [8] ) as important determinants of community acceptance. A second pathway focuses on the place-based approach [9]. This approach apprehends the locations of development as 'places' rather than sites or 'backyards' and argues that understanding responses to the energy technology 
project requires considering its potential to threaten the locality and to engender place protective action arising from the process of experiencing negative impacts on people-place relations and pre-existing emotional bonds $[9,10]$.

Within this perspective, not only the impact of energy infrastructures on landscapes (e.g., perceived visual impact; the noise generated by the mechanical components and the rotating blades of wind turbines) is the reason for opposition but also more importantly, how these technologies are perceived as disrupting or enhancing pre-existing emotional bonds [11]. In this line, people will support the energy technology project when they perceive that its visual impact is fitting in the place [12-14]. Batel et al. [15] show that people represent rural landscapes and energy infrastructures as having two different essences and that such (de-)essentialization, rooted in individual, relational, cultural, institutional, and political processes and practice, shape local responses to energy infrastructures.

Accordingly, it is our contention that breaking the NIMBYism requires a way of thinking that enhances our understanding of people's relationships to place. In fact, NIMBYism neglects the lived experience of places laden with emotions, cognitions, and behaviors that can trigger community acceptance of renewable energy. To develop a more holistic view of how people are connected with places and how the community experience of place might impact local responses to renewable energy projects, theoretical basis is gleaned from the place attachment community and the customer experience literature.

Typically, the community literature often emphasizes community emotional connections to place. These symbolic and affective concerns can motivate cooperative efforts as long as they are geared toward community improvement [16]. Furthermore, the tourism and environmental psychology literature have shown the importance of place attachment for understanding pro-environmental behavior and environmental concern [17-20]. The relevance of the role of place attachment appears particularly in the context of land use change contexts [21,22].

In addition to that, several studies have examined place attachment as an outcome variable predicted by place characteristics and activities e.g., [23] or as a predictor of customer loyalty (e.g., [24,25]). The various definitions of place attachment have contributed to the rise of research exploring its dimensions and measures in order to assess place-specific pro-environmental behaviors.

Yet despite the importance of place attachment for community planning, preservation, and development [26], positive community outcomes, and place protective actions [18,27], surprisingly few empirical studies investigate the place attachment in renewable energy farms $[9,28,29]$.

Furthermore, a review of the place attachment literature reveals that this concept is used interchangeably with similar concepts-sense of place, place meaning, place dependence and place identity - and there is no consensus on its dimensionality. While this concept is broadly defined and discussed in theory, its application in research does not fully embrace all the richness of the dimensions they suggest, thus revealing an important research gap. Unless the place attachment construct is not clearly understood, it may not be difficult for policy makers and developers to develop the citizen experience for renewable energy projects, to fit such projects and urban/rural place experiences, and for marketers to manage or control place behaviors.

In order to get a full understanding of place attachment, a crucial priority is to build up a suitable conceptual foundation and to take into consideration the context in which it operates. The research stream of experiential marketing conducted in different settings (e.g., brand, stores, and digital environments) and addressing experiences as sensory perceptions, feelings, knowledge, and actions [30] is deemed relevant to capture the whole aspects of attachment bonds with the local place where a renewable energy project is sited.

Customer experience has been conceived as an important factor in shaping and enhancing place attachment. Arguably, "commercial place attachment emerges from experiences of familiarity, authenticity and security offered by the commercial setting, and from the associated experience of homeyness" [31], (p. 905). However, customer 
experience in sites of development (such as renewable energy farms) is under-researched, and therefore, understanding place attachment may, in turn, help strengthen the resident, i.e., citizen experience in that place.

This paper addresses the research gap by investigating what is meant by place attachment through the lens of customer experience concept, particularly through the four dimensions as conceptualized by Schmitt and Zarantonello [32]: sensory-affective, cognitiveintellectual, social-relational and behavior-and-action oriented dimensions. Additionally, this study proposes a conceptual framework to understand the role of place attachment in shaping local responses toward renewable energy projects deployment. An empirical investigation was conducted to test the relevance of place attachment conceptualization in a specific context of climate change adaptation (e.g., proposals to site large-scale low-carbon energy technologies such as wind farms) and to test the relevance of the proposed model.

An interpretive phenomenological approach (IPA) is used to generate rich descriptions and detailed interpretation of how residents' lived experiences shape their responses to the local siting of renewable energy technologies, by examining specifically, how residents make sense of their lived experiences with the local place as well as the meanings they attribute to the project.

This article is organized as follows. First, an overview of place attachment, place disruption, and public responses to land use changes is provided. Second, the conceptual framework derived from our theoretical background is presented. Third, the methodology is presented. Subsequently, data analysis and the results offering empirical evidence on the meaning of the place attachment within the context of renewable energy projects deployment and highlighting the mechanisms underlying the problem of local opposition to the wind farm are presented. Finally, the study concludes with theoretical and practical implications, directions for future research, and limitations.

\section{Theoretical Background}

Place attachment is recognized as the bond between a person and a place that evolves from specifiable conditions of place and characteristics of people [33]. Many fields have investigated the place attachment concept. In sociology, most of the research underlined the social dimension of place attachment. This includes a strong emotional bond based on social relations with the physical aspect occupying an unimportant role. In Human Geography, place attachment is a universal phenomenon, which reflects a set of emotional and symbolic relationships between a person and his physical environment [34]. Thus, there is attachment as soon as the environment is perceived as a space making sense. In Environmental Psychology, Scannell and Gifford [35] have proposed a popular three-dimensional framework of place attachment encompassing person-process-place dimensions. The person component denotes individual place attachment based on individual experiences and personal connections and collective attachment created by the symbolic meanings of a place that are shared among members [36] and that arise from cultures, genders, and religions. The process component focuses on the psychological process including the feeling, cognitive, and behavioral facets of the person-place bond. The place component refers to the physical characteristics as well as the social and symbolic aspects of the place. For physical attachment, place attachment is directed toward the built and the natural environments of the site. The social place attachment rests on the place as an arena for social interactions or as a symbol for one's social group.

In the leisure tourism domain, research developed with reference to [37] identified three elements that comprise place attachment: place identity, place dependence, and place indifference. Place identity considers how a place is considered as essential to a person's self-identity and has emotional or symbolic meanings in people's lives. Place dependence refers to an attachment based on the functional utility of the place and its ability to satisfy a person's functional needs or behavioral goals. In addition, place dependence is expressed by concrete actions or behaviors from individuals [38]. Place indifference is the negative evaluations about the setting. 
Scholarship has described and provided empirical evidence of intensity and varieties of place attachment [12,39-41]. Five ways in which people may relate to their places of residence have been identified. Two forms of "senses of place" include people who were deeply attached to their place of residence had a strong place identity but differed in the extent to which their attachment was a product of the self-conscious attitude: (1) traditional attachment, designing an unselfconscious taken-for-granted bond to the residence place; (2) active attachment, which arises from a reflective and self-conscious bond along with an active interest in that place's events.

The three last forms describe types of sentiments toward places that implied a lack of place attachment. (3) "Place alienation" referring to a dislike of the place and estrangement from it, (4) "place relativity" designating an ambivalent and conditionally accepting attitude toward the place, and (5) "placelessness" meant an absence of emotional bonds with places and place indifference.

There is ample evidence from different field studies that place attachment relates to a variety of different behaviors such as residential mobility [41], civic activism [12], social well-being [42], and pro-environmental behaviors and attitudes such as "environmental sentiment" [43] or a "care for the wilderness" [44] and park visitors' citizenship behavior [45].

Devine-Wright [9] argued for the relevance of applying the concept of place attachment to climate change adaptation (e.g., by developing low-carbon energy technologies such as wind farms) and provided a framework of five stages for representing how place changes are understood. The first step consists of becoming aware of proposals for change through communication with trusted others, the media, and when private companies make public their proposals through public consultations or engagement processes.

Following awareness, individuals make sense of the environmental disruption on the individual and community level by identifying the change in terms of the physical and symbolic aspects of place. Then, individuals evaluate whether the impacts of the project are threating the place identity. Such judgment is founded upon place attachment and will lead to negative or positive evaluations of change. The fourth stage of the model is coping responses that involve the denial of that change or the avoidance. Such responses implicate "place-protective action" such as detachment from place, sending petitions to political representatives, addressing letters to newspapers or to policymakers or lobbying key actors, taking part in collective protest.

Twigger-Ross and Uzzell [46] examine the role of place in identity by using Breakwell's identity process model [47] as a theoretical framework. This model suggests continuity, self-esteem, self-efficacy, and distinctiveness as four principles of identity that guide action. The results show that these aspects of identity are grounded in the physical environment. In fact, attached residents consider their relationship with the local environment as supporting and developing the identity principles. Furthermore, the disruption of the place may imply disruption of identity. In this vein, Devine-Wright [9] in 2009 describes the third stage of the change model, the evaluation stage, in which projects may be interpreted to threaten placerelated distinctiveness (when the implanted technology stands for symbolic meanings contradictory to the local character), continuity over time (by altering the manner in which people experience joyful, familiar memories and places), self-efficacy (if the decisionmaking processes are believed to exclude the public members), which in turn reduce place-related self-esteem and trigger different forms of coping response and behavioral resistance.

Linking the model to place attachment, it was argued that strongly attached individuals may support technology proposals when these are interpreted as place enhancing.

Empirical research has supported this claim by showing that place attachment held by local residents can influence their willingness to accept energy technologies in that place $[10,28,29]$. 


\section{The Conceptual Framework}

To deepen our understanding of the role of place attachment in shaping local responses to renewable energy projects such as wind farms, this study proposes a framework relying on the input-process-output (IPO) model of team performance [48] and Devine-Wright's model [9] articulating stages of psychological responses over time to a place change.

Consistent with Stock's study [49], the structure of the proposed framework (Figure 1) is primarily based on the IPO model of team effectiveness indicating that output variables are determined by inputs and process variables where interpersonal and intrapersonal team characteristics, as part of the inputs, influence team effectiveness through the reduction of tensions hurting the team functioning and the enhancement of cooperation among members.

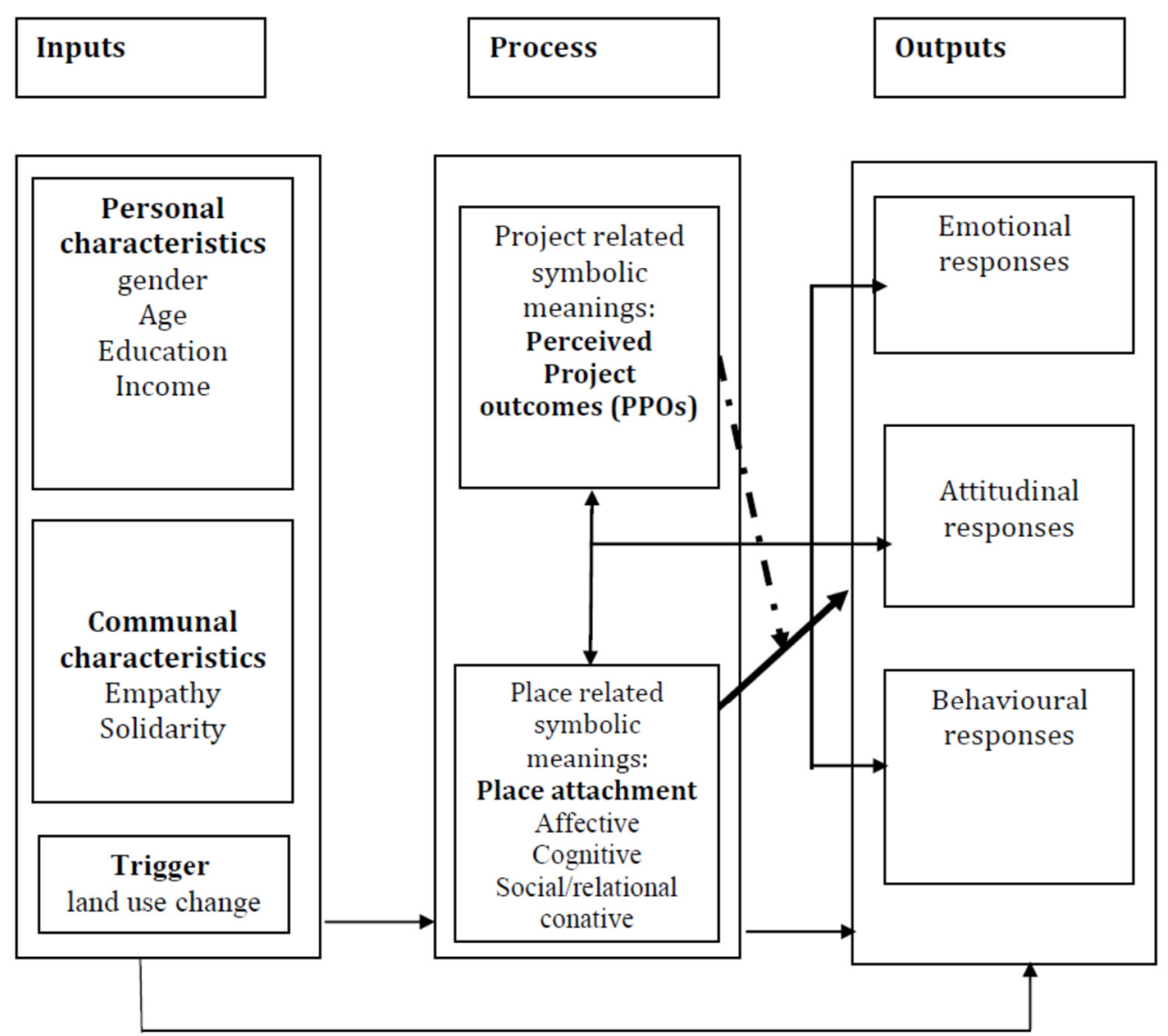

Figure 1. The role of place attachment in shaping local responses toward renewable energy projects deployment.

Accordingly, the model describes and explains local responses represented by community members' responses as outputs falling into three parts of emotions, attitudes, and behaviors and highlighting the two final stages of both coping and then acting as part of Devine-Wright (2009) 's model [9]. These outputs are driven by input variables and process variables. The input variables are the personal characteristics of community members and the characteristics of the community. The process consists in the interaction between the potential impacts of land use changes induced by the project as perceived by residents and their place attachment (Figure 1).

The whole phenomenon begins with the identification stage in which the trigger event elicits the local residents' awareness of the existence of a land use change. From this point, depending on personal member community characteristics and other communal characteristics, an interpretative psychological process will be executed by attributing specific symbolic meanings for the proposed project (as indicated by the Perceived Project 
Outcomes (PPOs)), and for the place as well (as indicated by place attachment) to make sense of the current change.

There remains a general neglect of research disentangling the mechanisms underlying the community acceptance of the RE project [50-52]. The current study stresses the articulation between symbolic meanings related to the specific place (indicated by place attachment) and those related to the project to be implemented (indicated by PPOs) as a psychological process determining the degree to which a development proposal would be accepted. When compared to the Devine-Wright (2009) framework [9], the psychological process of our model reflects the two stages of interpretation and evaluation.

Evaluation of change and particularly the perceived outcomes of the project interacts with place attachment to influence community acceptance or opposition of the project. Consistent with extant research that advocates the role of place attachment in proenvironmental behavior, place attachment positively affects the acceptance of the project. This positive effect becomes particularly important at higher levels of positive perceived outcomes because residents will relatively easily cope with positive changes.

Negative perceived outcomes are likely to disrupt the positive effect of place attachment on project acceptance. According to the potential value of the development projects, these will disrupt or foster place attachment and cause favorable or negative reactions. When residents perceive positive outcomes, place attachment fosters positive public reaction. When a development project is negatively evaluated, the project will disrupt place attachment, disturb a sense of continuity [53], and community members will be more likely to feel loss and alienation [40] and to be mobilized toward protective action. This is consistent with the argument of place attachment disruption [53] and IPT [47].

According to the coping and acting stages, the two final stages in Devine-Wright (2009) 's model [9], local residents will react to the proposal for change either by accepting or denying it and accordingly will take actions in support of the project or engage in oppositional behaviors as forms of place protective actions.

\section{Methodology}

This study adopts a qualitative research method to explore the interpretive process of community acceptance/opposition to the renewable energy project and to grasp how locals ascribe symbolic meanings to their socio-physical environment. Consistent with the call of [54], we used an interpretive phenomenological approach (IPA) to explore the manifestation of place attachment in residents' lived experiences with the deployment of wind energy project; specifically, what community members feel and think as well as the meanings they attribute to the local place where they live and to the wind energy farm. IPA integrates together phenomenology and hermeneutics, enabling a description and interpretation of the phenomenon, and it relies on idiography by focusing on a detailed case exploration [55], (p.8). Such a phenomenological perspective is used to understand through subjective narratives the experience as it is "lived" [56,57].

In order to apply theory to practice, a case study around the wind power station installed in the village of Sidi Daoud located in Northeast Tunisia was conducted, where we carried out our interviews. Data were collected through phenomenological interviews exploring the resident personal experiences with Sidi Daoud and with the wind farm.

Informants who took part in the phenomenological interview were recruited through the snowball technique whereby the initial participants were asked to identify others. A varied sample of 23 informants in terms of socioeconomic profile and age was obtained. With the format of the semi-structured interview, the interviewer has the spontaneity and the freedom to probe and explore the meaning of the place attachment within the context of land use changes and the mechanisms underlying the problem of local opposition to renewable energy developments. Each interview lasted approximately between 45 and 60 min, and all the interviews were fully audio-recorded and subsequently transcribed. 


\section{Data Analysis and Results}

Results include themes that incorporate place attachment as well as themes highlighting the role of place attachment in local public responses to proposals for change.

We identified the themes related to people-place bonds forming place attachment experiences. The findings are structured around four key themes that emerged during the analysis through the lens of the experiential approach and following the work of [32]. place attachment consists in four dimensions, corresponding to each experience component as follows:

- Affective: Emotional link and sharing of values with the place.

- Cognitive: emerges when a place instills meanings, memories, schemas, and knowledge leading to place identity.

- Conative: This dimension represents behavioral commitments toward the place. It incorporates particularly place dependence that has been widely considered in the place attachment literature.

- Social-Relational: This aspect of attachment is based on social bonds that stem from the interactions arising within the place and on the relationship with the environment.

Our results suggest that person-place bonding arises from personal involvement at different levels of experience: emotional, social, cognitive, and conative, in which individuals construe meaning about their socio-physical environment. These bonds were encountered in both gender groups of the interviewed participants and among young and old people, and they are most frequently expressed by people with poor financial situations irrespective of their levels of educational attainment.

For many of the themes, our results suggest that reactions were strongly linked to how residents perceive project outcomes and how land change may alter their connections within that place. Some differences in socio-demographic characteristics were observed in residents' reactions. A lower level of educational and income played a role in influencing objections to the wind energy project.

\subsection{Meaning Attributed to Place Attachment}

The interpretation of place attachment through the lens of the proposed customer experience shows how place meanings are intertwined with emotional, social, cognitive, and conative bond.

\subsubsection{Affective Bond}

Emotional themes were associated with enjoying the familiarity, the security, the confidence, and the comfort in Sidi Daoued; as respondents emotively advocate, "Sidi Daoud is a part of me, of who I am ... ", "In Sidi Daoud you are at home, ... ", "It's a beautiful natural, safe place.", "Being surrounded by trustworthy people makes me feel relieved and comfortable". "What I do really feel for Sidi Daoud makes it different for me; "I can strongly identify myself around here ..."

A number of reasons stand behind participants' familiarity with the places they lived in for so long. Their close association with the entourage in addition to their close acquaintance with the buildings and vista of Sidi Daoud are strong explanatory factors of their feeling of familiarity.

We noticed respondents feeling at ease in Sidi Daoud and not feeling the same in another place, "of course I'm more comfortable here; I can express my beliefs, my thoughts without having that fear of being misunderstood ... somewhere else, I would definitely think double times before saying anything ... ", "I do feel comfortable in other places especially when surrounded by my family's members but not to the degree of Sidi Daoud ..."

A comment that is complemented by two other respondents who have been away from home for a while highlighted that even with the absence of tangible contact, maintaining connection to Sidi Daoud was still possible through emotive contact: "Physically speaking, I was hundreds of kilometers away from home, but my soul, thoughts, and emotions were with my family in Sidi Daoud." 
Disposing of a considerable acquaintance with or knowledge of Sidi Daoud instills security, confidence, and comfort in people.

The natural and geographic situation of Sidi Daoud characterized by mountains, hills, large green spaces, and spectacular sea views was equally symbolic and evocative of emotional experience. "It's pretty unbelievable, warm, and relaxing to feel and breath the refreshing air each day once you woke up in the morning." " "I just love looking outside the window and seeing the mountains glistening in the horizon ... " as expressed by one of the interviewees.

We observed that values play a key role in enhancing the attachment by bringing the group together and enabling the lived experience. Living in Sidi Daoud was reflective of someone's traits and values. The simplest things, even those that might appear to be silly to you (waiting for your husband late at night and not having dinner unless he comes back from work, not stepping over elder people, taking your shoes off before going inside someone's dwelling ... ) go beyond regular, daily, and insignificant acts to reflect a particular way of being inside the village of Sidi Daoud.

\subsubsection{Social/Relational Bond}

Other frequently mentioned reasons fall into the 'relational' category. Amongst these relationship-related meanings, connection and continuity were mentioned most often, which were intertwined with family and friends.

Our findings suggest that sharing the same identity, the same native land, or country of origin facilitates being more connected with people:

"In Sidi Daoud, I can easily communicate, build relationships, and interact with people; however, in other places, I become more distrustful and afraid of being rejected because I'm different." " ... We were part of a big family in a small village ... All people knew each other".

In addition to connection, we observed that continuity also influenced attachment in the sense that both relatedness to people and connectedness to the land need to be maintained for future generations.

"It's about my deep sense of identification to a place, it's about recognizing my origins and letting my kids and their kids know where they originate or hail from."

A young man declared having little to do with Sidi Daoud, but the place meant something for him because it is important in the life of his relatives and beloved ones.

"I used to make frequent visits to my grandparents who keep telling me stories about Sidi Daoud and about their connection to the land and to the sea ..."

\subsubsection{Cognitive Bond}

The symbolic meanings developed from cognitive ties attributed to Sidi Daoud was another reason that also influenced place-based motivations and the overall experience. Sidi Daoud has been pictured, for most respondents, as a landmark for emotionally significant past experiences and memories.

When we ask what is the first thoughts coming to one's mind, what Sidi Daoud really meant to respondents, memories of joy, love, pride, sadness ... were consistently apparent in the interviewees' speeches.

“Can't forget how proud I was, to share even little time with President Habib Bourguiba in the island of Zembra ... Located $15 \mathrm{Km}$ away from here, president Bouguiba used to go there by plane and we used to follow him by our own fishing boats ..."

When asked about the kind of things symbolizing Sidi Daoud, particular persons (aunties, parents, uncles, grandparents ... ) and reminiscences related to those people come across the respondents' minds. Sidi Daoud was particularly symbolizing a mixture 
of local activities such as fishing, sheep grazing, cattle ranching, and cultivation in addition to building up and strengthening relationships with family members, neighbors, and old friends. "The seasonal fishing of bluefin Tuna and the use of the 'madrague' technique is a powerful symbol of Sidi Daoud."

Sidi Daoud is conceived as both a container of memory and a significant place for important people. For most respondents, Sidi Daoud was a place to catch up with family members, neighbors, and childhood friends; it was also remembered as a great playground and a place of gatherings such as traditional family assemblies and local weddings ...

"I shared a lot of memories in Sidi Daoud ... I can remember everything that has happened to me as if it were yesterday ..."

"As a child, I grow up like most of the kids in here, we used to create our own fun, play with toys made by our hands. Life used to be so simple and tough at the same time but we enjoyed being raised in the nature and we enjoyed discovering different species of animals and plants."

\subsubsection{Conative Bond}

The most often cited reason that makes a place as meaningful was that it enabled people to perform their job within the society and to contribute to the social life of Sidi Daoud and to the development of the local region.

Respondents evoked participation as means for sustainment of their connection to the place. The tendency of individuals from the local community to engage in activities aiming at improving the local economy, job creation, and increasing society's living standards merely by making rational use of the current features of the area is a mark of place attachment. The citizen's experience of engagement in the maintenance and the development process highlights another aspect of a human bonding to a particular place.

More than three-quarters of the respondents reported a willingness to take action to preserve and develop this place.

Two participants proclaimed having a responsibility to assume toward the village:

"As a mother raising two children, I must continue keeping our own culture, traditions, and customs alive for future generations ..."

"We should all contribute to preserving our own identity and lifestyles ..."

"We should be responsible to our children, we have to create a better place of living and feel blessed with what we got instead of running away from it ... "

\subsection{The Role of Place Attachment in Local Public Responses to Proposals for Change}

To better understand land change impacts on residents' place connection, and the ways that people-place relations affect their responses to the wind energy project, we asked open-ended questions distinguishing the pre-and post-implementation periods, which indirectly revealed the interviewees' own judgments of the PPOs with regard to the disruption or valuing of their pre-established bonds with Sidi Daoud.

Indeed, the same project outcomes could be assessed differently by two participants due to their perceptions that differ according to their attachment to the place and their personal characteristics. Each interviewee insisted on the aspects he found to be most affected by the project.

Yet interpreted from a customer experience research perspective, the results show that the implementation of wind energy project affects the sensory features of the local place and individuals' lived experiences. According to how individuals perceive the impacts of the wind farm, place attachment is related to the local residents' support or opposition. Place attachment reduces the objections to the siting of wind energy technology as long as it sustains and enhances (1) past emotional experiences by altering one's inner feelings and affective relations to the setting (2) the pre-lived relational experiences within social contexts (3) the cognitive meanings attributed to place representations, memories, 
knowledge and beliefs through place experience (4) behavioral intentions to maintain connections to place and commitments.

In what follows, we have discerned the residents' perceptions of the project outcomes in accordance to their influence on the place attachment aspects:

\subsubsection{The Impact of PPOs on Emotional Place Meanings}

An important question for a deeper understanding of this topic is whether those levels of both familiarity and comfort are kept the same since the implementation of the wind farm project. Some residents complained about not feeling "secure" and "comfortable" anymore especially because the village has become "... more crowded, there is an increasing number of visitors who are interested in discovering the milieu ... " which consequently led to more thefts...

The sense of belonging is still perceived positively by residents with the wind farm. Residents have something more in common to share and to add to their personal experiences of involvement in Sidi Daoud. They are very proud of living in this area "I [am] still proud of myself as a citizen, I feel myself as an integral part of Sidi Daoud ... Why wouldn't I?? The physical evolution of the village and the existence of the wind park is axiomatic ... it's totally normal and I consider it for the best interest of all the village," reported a young adult.

\subsubsection{The Impact of PPOs on Social Place Meanings}

Interviews with local residents revealed that the place changes have preserved a sense of continuity in their lives and did not threaten the relational and social configurations that underpin their attachment to that place.

Elder respondents also reported that ensuring continuity for future generations along with safeguarding distinctiveness and symbolism, even creating new, typical, representative and most importantly favorable features for the place has been made possible through the betterment of life conditions in Sidi Daoud.

According to a number of participants, the industrialization of the urban area "even to a small degree" has contributed to resolving issues of internal displacement, which is evidently shown in these replies: "The traffic is speedier now ... buses become available ... The existence of driveways has facilitated our daily life ... in addition to alleviating unemployment".

Such an improvement could have been postponed for an unknown date without the choice of Sidi Daoud as a building site for the first wind energy station in Tunisia.

The implementation of the wind park did not only offer better chances of living connected in Sidi Daoud for the present time but also increased the likelihood for future generations to keep on living there on an ongoing or steady basis; and that is how the sense of continuity was preserved.

The renewable energy development itself could represent a way to attract people (tourists and investors) from the inside and outside of the village, which helps foster social development, stimulate the economy, and improve standards of living. Just like that, citizens who will be given more reasons to stay in Sidi Daoud, develop their sense of continuity, and fortify their connection to the place.

Conversely, some interviewees evaluate the project outcomes as disturbing their social and relational experience within the place.

The industrialization outcome was evaluated as having a remarkable and negative influence on Sidi Daoud as a social and physical construction. In fact, the project has exploited a significant part of the green and fertile land for the construction of the project and for the upgrading of access routes. The disposal of solid and liquid wastes, for the entire time the wind power plant is in operation, polluted the soil, the water surface, and the water ground, which equally led to the deterioration in the community's fisheries and agricultural situation. 
In other words, two vital activities in Sidi Daoud have been downgraded, which suspended the sense of continuity among residents, undermined their commitment to the place, restrained their efforts in pursuit of better living conditions, and precluded attachment.

The following response is reflective of the experiences of most landowners in Sidi Daoud: "My father gave away 2 hectares of green land which caused a double loss for us: Our agricultural activity was fully affected, besides we didn't receive any indemnities ... We didn't only lose our land, we lost hope, we lost what connects us to Sidi Daoud."

This example shows a sense of alienation from a place as an outcome of change for strongly attached individuals to that place.

In another example, an interviewee stated: "We moved on to the downtown area in search for better opportunities of decent living".

Some community members experience painful loss of their land that induced a traumatic loss of bonds due to mobility as well as their coping or adaptive value to address land change and disruption. They became "detached" from the place.

This change impacted Sidi Daoud as a relational tool as it reduced communicative interaction between members of the same family and between friends and members of local community in general.

\subsubsection{The Impact of PPOs on Cognitive Place Meanings}

Most of the residents' participants furthermore avowed how place meanings associated with their thoughts and memories are preserved and even become rich.

Sidi Daoud was, from the very first beginning, a symbol of " 243 windy days a year" in addition of being a sign of "tuna fish", "la madrague or trap nets". With the implementation of the wind station, Sidi Daoud has become even more distinctive with its climatic condition. Sidi Daoud is now called "the village of aerogenerators", "the village of wind turbines".

The distinctiveness and the symbolism of the place as perceived by its inhabitants (the ruralization of the area, the physical attributes of the place, and the specific characteristics of its people) was retained even with the existence of aerogenerators around the place.

Some local residents still consider the location to be "natural" and suitable for a wind project. In fact, the Sidi Daoud zone was weakly urbanized: "I still enjoy the rural life style" and the exploitation of this type of plant did not generate significant changes. Instead, it has given a certain aesthetic charm to the site through the harmonious integration of the wind turbines into the landscape.

Similar findings were reported in Devine-Wright's study [29] that place changes were positively esteemed by residents and had boosted perceptions of local distinctiveness.

In amongst the outcomes, other respondents mentioned the noise emissions caused by the generators and the rotation of airfoils for the power wind turbines. Such a PO eroded distinctiveness as residents complained about not getting "enough sleep" or having their "good night's sleep ruined". The region has lost its calm and pleasant atmosphere ever since the aerogenerators were installed. Such changes to the place have created a place that has lost its personal meaning or character.

\subsubsection{The Impact of PPOs on Conative Place Meanings}

Place attachment reduces the objections to the siting of renewable energy projects as long as the meanings associated with that place impacted by a wind farm is enhanced by an array of activity-based working. The participants in this study highlighted the bright side of the project outcomes and the favorable blending between the project outcomes and the conative aspect of place attachment. Residents' strong support for the RE project stems from their involvement in discussing, planning, and/or actively taking part in the project's development.

Place meanings are embedded within different activities that are related to the development of an RE project. Participants expressed the importance of involving the public 
in planning for acceptance and for the sustainment of place meanings in this context of landscape change, explaining, "Community members need to be more involved".

Narratives elucidate that people feel care for the community because they have a richer understanding of the nature and they feel the emotions of others. They support residents implicated in siting disputes. Their engagement with the environment disposes them to take coordinated collective action to resolve conflicts over locally unwanted land uses. They assume that they share local concerns and that solidarity is their principle and it is a pathway for realizing sustainability.

The role of empathy in fostering coordinated collective action to address sustainability challenges supports the findings of previous studies [58].

\section{Discussion}

We tried to iteratively synthesize theory and field-based insights to test the relevance of place attachment conceptualization in a specific global challenge, i.e., renewable energy transitions and the relevance of the proposed integrative framework.

Our findings capture the meaning of place attachment in such specific context of citizen experience as related to a site for development and prove how the place attachment construct applied to a renewable energy setting arises from different types of individuals experiences of place, i.e., cognitive, affective, behavioral and social experiences [32]. These psychological aspects manifested in the place attachment, i.e., affect (the emotional experience in a place), cognition (memories, beliefs, meaning, and knowledge associated with the place), behavior (behavioral commitments toward the place), and relational (socially based place bond) reflect the way that individuals interact with their beloved place.

In addition, exploratory analysis reveals that public responses to the renewable energy project, emerge from the interplay of attributing symbolic meanings to both place and project and deciding on the degree of their alignment. The symbolic meanings of the project, as reflected in the PPOs, are likely to enhance or disrupt place attachment depending on the "fit" of renewable energy development project and the local place, which in turn determine the ways people respond to such land use change.

Rural residents, who oppose to the wind energy farm, view the project as spoiling their emotional experience in the place, their memories, beliefs, meaning, and knowledge associated with the place, their social based place bond and their behavioral commitments toward the place. When the project is perceived as not disrupting the place meanings that value natural beauty and not ruining the landscape, and then praising the lived experience of local residents, it is more likely to be supported.

Besides, the findings affirm the relevance of place attachment in shaping local responses in different ways according to the impacts of renewable energy project. The sign of progress and the perceived novelty of the wind farm project (e.g., rural infrastructure improvement, opportunities for local employment, opportunities for sharing experiences, opportunities for building contacts ... ) induce more favorable attitudes towards renewable energy project when rural people are more attached to their place. Conversely, when the perceived outcomes of the wind farm are negative, wind energy technology represents a more disturbing change in the beloved place for more attached people.

We showed that the acceptance of wind farm can be affected by the emotional, cognitive, social and behavioral bond one has with the place. While place attachment can enhance one to explore and praise the possibilities afforded by a project of renewable energy technologies with positive impact, it can also induce higher objections and skepticism towards negative impactful development proposal.

These results are in line with literature suggesting that attached people are more willing to engage in pro-social and pro-environmental behaviors $[18,26,27]$ and to explore new possibilities that contribute to community wellbeing [59].

Our findings support and extend work assuming that what is important for the supportive attitudes to renewable energy projects is how these wind development proposals are interpreted and evaluated rather than the transformative changes per se (e.g., [14,15]). 
Overall, the in-depth analysis of the experiences of participants reveals a moderating effect of the PPOs (bold arrow in Figure 1). The PPOs is the condition under which place attachments enable or constrain the acceptance: place attachment is linked to community objections in situations where a wind energy technology is perceived to obstruct place experience-related cognitive, affective, social, and conative aspects rather than to enhance such place experiences.

Finally, we show that specific characteristics of the host community play an indispensable role in the success of renewable energy projects. Empathy and solidarity of the host community motivate cooperative efforts that facilitate collective sustainable responses to local energy proposals.

\section{Conclusions}

The main objective of this study is to provide insightful evidence of an alternative to the 'NIMBY' explanation by investigating the relative importance of place and projectrelated meanings as well as community characteristics in explaining the acceptance of the renewable energy project.

Specifically, firstly, we identify what is meant by place attachment, and due to the complexity involved in capturing the dimensions of place attachment, we build on the customer experience work of [32] to propose the facets encompassing place attachment that are believed to fit with and to cover the various aspects of place attachment. Thus, as community members develop experiences with the place, the cognitive, affective, social, and behavioral levels contribute to the formation of place attachment.

Second, we develop a conceptual model that explores how place attachment underpins community responses to the renewable energy project. In line with literature addressing other kinds of land use changes (e.g., [22]), this study values the role of "symbolic meanings" by elaborating a conceptual framework that underlines the logic of interaction between symbolic meanings related to both project and setting proposed for development as a determinant factor of local community acceptance.

The findings also suggest that in line with [10], the role of sociodemographic characteristics in influencing renewable energy project acceptance is highly context specific. Narratives revealed that empathy and solidarity, as characteristics of the host community, obstruct opposition to the wind energy project by creating emotional, cognitive, conative, and social bonds with the local place that address the challenges faced in siting wind energy farms.

In terms of practical implications, policy makers would benefit from greater awareness of the ways local residents contest / accept energy infrastructure projects and that must be taken into consideration when planning and implementing land-use changes. Planners need to recognize the value and symbolic meanings of local place. In this vein, it is crucial to dig deeply into the emotional, cognitive, social and behavioral bonds that people have with their local place, over the planning process and the project management to address the challenges in wind energy park installation. Therefore, there is a need to consider the local specific social, economic, cultural, historical and geographical context in addition to the technical configuration.

Understanding how residents are connected with and attribute meanings to the local place can help project managers segment the population to target outreach and action [60]. Place meanings can be used by managers as a means of communication to change behaviors among the residents.

Whilst the results highlight the importance of the congruence among the symbolic meanings associated with place and renewable energy project in shaping community acceptance, the interplay of local perception of trust in stakeholders (local authorities, developers, community representatives' groups ... ) $[8,61]$ and the fairness of decisionmaking processes [7] could be in addition explored.

This research established the roots of place attachment formation that can be used in future research for scale development. 
The current study was conducted in one country, Tunisia, and at a wind energy farm, thus limiting the scope of the study. Future research may extend the current study for other form of renewable energy technology, and quantitative study could test the model in other contexts, providing cross-cultural perspectives for the generalizability of the proposed model. Longitudinal research could examine the dynamic of the impact of place attachment and PPOs on local community acceptance/resistance at different life stages over time.

Author Contributions: Conceptualization, S.M.H.; methodology, H.A.A.M.; validation, S.M.H. and H.A.A.M.; formal analysis, S.M.H.; investigation, S.M.H.; resources, H.A.A.M.; data curation, H.A.A.M.; writing-S.M.H.; writing—review and editing, S.M.H.; supervision, S.M.H. Both authors have read and agreed to the published version of the manuscript.

Funding: This research project was supported by a grant from the Research Center for the Humanities, Deanship of Scientific Research, King Saud University. Research Group No. (HRGP-1-19-01).

Informed Consent Statement: Informed consent was obtained from all subjects involved in the study. Data Availability Statement: Not applicable.

Acknowledgments: The authors extend their appreciation to Chtourou Sahar for her helpful implication in data collection.

Conflicts of Interest: The authors declare no conflict of interest.

\section{References}

1. IPCC. Intergovernmental Panel on Climate Change. Global Warming of 1.5 Degrees; Special Report of the IPCC; IPCC: London, UK, 2018.

2. Devine-Wright, P. Beyond NIMBYISM: Towards an Integrated Framework for Understanding Public Perceptions of Wind Energy. Wind Energy 2005, 8, 125-139. [CrossRef]

3. Bell, D.; Gray, T.; Haggett, C. The 'Social Gap' in wind farm siting decisions: Explanations and policy responses. Env. Polit 2005, 14, 460-477. [CrossRef]

4. Jones, C.R.; Eiser, J.R. Understanding 'local' opposition to wind development in the UK: How big is a backyard? Energy Policy 2010, 38, 3106-3117. [CrossRef]

5. Warren, C.R.; Lumsden, C.; O’Dowd, S.; Birnie, R.V. ‘Green On Green': Public Perceptions of Wind Power in Scotland and Ireland. J. Environ. Plan. Manag. 2005, 48, 853-875. [CrossRef]

6. Midden, C.; Huijts, N. The role of trust in the affective evaluation of novel risks: The case of $\mathrm{CO}_{2}$ storage. Risk Anal. 2009, 29, 743-751. [CrossRef]

7. Gross, C. Community perspectives of wind energy in Australia: The application of a justice and community fairness framework to increase social acceptance. Energy Policy 2007, 35, 2727-2736. [CrossRef]

8. Walker, G.; Cass, N.; Devine-Wright, P. Good neighbours, public relations and bribes: The politics and perceptions of community benefit provision in renewable energy development in the UK. J. Environ. Policy Plan. 2010, 12, 255-275.

9. Devine-Wright, P. Rethinking NIMBYism: The Role of Place Attachment and Place Identity in Explaining Place-protective Action. J. Community Appl. Soc. Psychol. 2009, 19, 426-441. [CrossRef]

10. Devine-Wright, P. Explaining "NIMBY" Objections to a Power Line: The Role of Personal, Place Attachment and Project-Related Factors. Environ. Behav. 2013, 45, 761-781. [CrossRef]

11. Fornara, F.; Scopelliti, M.; Carrus, G.; Bonnes, M.; Bonaiuto, M. Place attachment and environment-related behavior. In Place Attachment: Advances in Theory, Methods and Applications, 2nd ed.; Manzo, L., Devine-Wright, P., Eds.; Routledge: Abingdon, UK, 2020; Chapter 12. [CrossRef]

12. Lewicka, M. Ways to make people active: Role of place attachment, cultural capital and neighborhood ties. J. Environ. Psychol. 2005, 4, 381-395. [CrossRef]

13. Wolsink, M. Wind power and the NIMBY-myth: Institutional capacity and the limited significance of public support. Renew. Energy 2000, 21, 49-64. [CrossRef]

14. Devine-Wright, P.; Wiersma, B. Understanding community acceptance of a potential offshore wind energy project in different locations: An island-based analysis of 'place-technology fit'. Energy Policy 2020, 137, 111086. [CrossRef]

15. Batel, S.; Devine-Wright, P.; Wold, L.; Egeland, H.; Jacobsen, G.; Aas, O. The role of (de-)essentialisation within siting conflicts: An interdisciplinary approach. J. Environ. Psychol. 2015, 44, 149-159. [CrossRef]

16. Perkins, D.D.; Long, D.A. Neighborhood sense of community and social capital: A multi-level analysis. In Psychological Sense of Community: Research, Applications, and Implications; Fisher, A., Sonn, C., Bishop, B., Eds.; Plenum: New York, NY, USA, 2002; pp. 291-318.

17. Cheng, T.M.; CWu, H.; Huang, L.M. The influence of place attachment on the relationship between destination attractiveness and environmentally responsible behavior for island tourism in Penghu, Taiwan. J. Sustain. Tour. 2012, 21, 1166-1187. [CrossRef] 
18. Halpenny, E.A. Pro-environmental behaviours and park visitors: The effect of place attachment. J. Environ. Psychol. 2010, 30, 409-421. [CrossRef]

19. Ramkissoon, H.; Smith, L.D.G.; Kneebone, S. Visitor Satisfaction and Place Attachment in National Parks Tourism. Tour. Analysis 2014, 19, 287-300. [CrossRef]

20. Song, Z.; Daryanto, A.; Soopramanien, D. Place attachment, trust and mobility: Three-way interaction effect on urban residents' environmental citizenship behavior. J. Bus. Res. 2019, 105, 168-177. [CrossRef]

21. Devine-Wright, P.; Quinn, T. Dynamics of place attachment in a climate changed world. In Place Attachment: Advances in Theory, Methods and Applications, 2nd ed.; Manzo, L., Devine-Wright, P., Eds.; Routledge: Abingdon, UK, 2020; Chapter 14. [CrossRef]

22. Stedman, R.C. Toward a social psychology of place: Predicting behavior from place-based cognitions, attitude and identity. Environ. Behav. 2002, 34, 561-581. [CrossRef]

23. Gross, M.J.; Brown, G. An empirical structure model of tourists and places: Progressing involvement and place attachment into tourism. Tour. Manag. 2008, 29, 1141-1151. [CrossRef]

24. Hwang, S.; Lee, C.; Chen, H. The relationship among tourists' involvement, place attachment and interpretation satisfaction in Taiwan's national parks. Tour. Manag. 2005, 26, 143-156. [CrossRef]

25. Yuksel, A.; Yuksel, F.; Bilim, Y. Destination attachment: Effects on customer satisfaction and cognitive, affective and conative loyalty. Tour. Manag. 2010, 31, 274-284. [CrossRef]

26. Manzo, L.C.; Perkins, D.D. Finding Common Ground: The Importance of Place Attachment to Community Participation and Planning. J. Plan. Lit. 2006, 20, 335-350. [CrossRef]

27. Walker, G.J.; Chapman, R. Thinking like a park: The effects of sense of place, perspective-taking, and empathy on proenvironmental intentions. J. Park Recreation Admin. 2003, 21, 71-86.

28. Devine-Wright, P.; Howes, Y. Disruption to place attachment and the protection of restorative environments: A wind energy case study. J. Environ. Psychol. 2010, 30, 271-280. [CrossRef]

29. Devine-Wright, P. Place attachment and public acceptance of renewable energy: A tidal energy case study. J. Environ. Psychol. 2011, 31, 336-343. [CrossRef]

30. Brakus, J.J.; Schmitt, B.H.; Zarantonello, L. Brand Experience: What Is It? How Is It Measured? Does It Affect Loyalty? J. Mark. 2009, 73, 52-68. [CrossRef]

31. Debenedetti, A.; Harmen, O.; Zeynep, A. Place Attachment in Commercial Settings: A Gift Economy Perspective, J. Consum. Res. 2014, 40, 904-923. [CrossRef]

32. Schmitt, B.; Zarantonello, L. Consumer experience and experiential marketing: A critical review. Rev. Mark. Res. 2013, 10, 25-61.

33. Shumaker, S.A.; Taylor, R.B. Toward a Clarification of People-Place Relationships: A Model of Attachment to Place. In Environmental Psychology: Directions and Perspectives; Feimer, N.R., Geller, E.S., Eds.; Praeger: New York, NY, USA, 1983.

34. Tuan, Y.F. Space and Place: The Perspective of Experience; University of Minnesota Press: Mineapolis, MN, USA, 1977.

35. Scannell, L.; Gifford, R. Defining place attachment: A tripartite organizing framework. J. Environ. Psychol. 2010, 30, 1-10. [CrossRef]

36. Altman, I.; Low, S.M. Place Attachment; Plenum: New York, NY, USA, 1992.

37. Williams, D.R.; Roggenbuck, J.R. Measuring place attachment: Some preliminary results. In Proceedings of the Session on Outdoor Planning and Management NRPA Symposium on Leisure Research, San Antonio, TX, USA, 20-22 October 1989.

38. Williams, D.R.; Patterson, M.E.; Roggenbuck, J.H.; Watson, A.E. Beyond the commodity metaphor: Examining emotional and symbolic attachment to place. Leis. Sci. 1992, 14, 29-46. [CrossRef]

39. Devine-Wright, P.; Batel, S. My neighbourhood, my country or my planet? The influence of multiple place attachments and climate change concern on social acceptance of energy infrastructure. Glob. Environ. Chang. 2017, 47, 110-120. [CrossRef]

40. Hummon, D.M. Community attachment. Local sentiment and sense of place. In Place Attachment; Altman, I., Low, S.M., Eds.; Plenum Press: New York, NY, USA; London, UK, 1992; pp. 253-277.

41. Bailey, E.; Devine-Wright, P.; Batel., S. Emplacing linked lives: A qualitative approach to understanding the co-evolution of residential mobility and place attachment formation over time. J. Commun. Appl. Soc. Psychol. 2021. [CrossRef]

42. Rollero, C.; De Piccoli, N. Does place attachment affect social well-being? Rev. Eur. Psychol. Appl. 2010, 60, 233-238. [CrossRef]

43. Langenau, E.E.; Peyton, R.B.; Wickham, J.M.; Caverney, E.W.; Johnston, D.W. Attitudes toward oil and gas development among forest recreationists. J. Leis. Res. 1984, 16, 161-177. [CrossRef]

44. Borrie, W.T.; Roggenbuck, J.R. The dynamic, emergent, and multi-phasic nature of on-site wilderness experiences. J. Leis. Res. 2001, 33, 202-228. [CrossRef]

45. Ramkissoon, H.; Mavondo, F.; Uysal, M. Social involvement and park citizen ship as moderators for quality-of-life in a national park. J. Sustain. Tour. 2018, 26, 341-361. [CrossRef]

46. Twigger-Ross, C.L.; Uzzell, D.L. Place and identity processes. J. Environ. Psychol. 1996, 16, 205-220. [CrossRef]

47. Breakwell, G.M. Coping with Threatened Identity; Methuen: London, UK, 1986.

48. McGrath, J.E. Social Psychology: A Brief Introduction; Holt, Rinehart and Winston: New York, NY, USA, 1964.

49. Stock, R.M. How Should Customers Be Integrated for Effective Interorganizational NPD Teams? An Input-Process-Output Perspective. J. Product. Innov. Manag. 2014, 14, 35-47. [CrossRef] 
50. Mjahed Hammami, S.; Chtourou, S.; Triki, A. Place attachment in land use changes: Going beyond nimbysm in the case of renewable energy project deployment. In Proceedings of the Annual Academy of Marketing Conference, 2014, London, UK, 7-10 July 2014.

51. Mjahed Hammami, S.; Chtourou, S.; Triki, A. Identifying the determinants of community acceptance of renewable energy technologies: The case study of a wind energy project from Tunisia. Renew. Sustain. Energy Reviews 2016, 54, 151-160. [CrossRef]

52. Mjahed Hammami, S.; Chtourou, S.; Al Moosa, H. A Holistic Approach to Understanding the Acceptance of Community Based Renewable Energy Project: A Pathway to Sustainability for Tunisia's Rural Region. Bus. Strategy Environ. 2018, 27, 1535-1545. [CrossRef]

53. Brown, B.B.; Perkins, D. Disruptions in place attachment. In Place Attachment; Irwin, A., Setha, L., Eds.; Plenum: New York, NY, USA, 1992.

54. Batel, S.; Devine-Wright, P. Using NIMBY rhetoric as a political resource to negotiate responses to local energy infrastructure: A power line case study. Local Environ. 2020, 25, 1-13. [CrossRef]

55. Pietkiewicz, I.; Smith, J.A. A practical guide to using interpretative phenomenological analysis in qualitative research psychology. Psychol. J. 2014, 20, 7-14.

56. Arsel, Z. Asking Questions with Reflexive Focus: A Tutorial on Designing and Conducting Interviews. J. Consum. Res. 2017, 44, 939-948. [CrossRef]

57. Thompson, C.J.; Locander, W.B.; Pollio, H.R. Putting Consumer Experience Back into Consumer Research: The Philosophy and Method of Existential-Phenomenology. J. Consum. Res. 1989, 16, 133-146. [CrossRef]

58. Brown, K.; Adger, W.N.; Devine-Wright, P.; Anderies, J.M.; Barr, S.; Bousquet, F.; Butler, C.; Evans, L.; Marshall, N.; Quinn, T. Empathy, place and identity interactions for sustainability. Glob. Environ. Chang. 2019, 56, 11-17. [CrossRef]

59. Wnuk, A.; Oleksy, T. Place attachment and acceptance of smart city technologies. In Proceedings of the 54th Hawaii International Conference on System Sciences, Honolulu, HI, USA, 5-8 January 2021. [CrossRef]

60. Simoni, J.; Floress, K. An exploration of place meanings among residents in central Wisconsin. Lake Reserv. Manag. 2015, 31, 1-10. [CrossRef]

61. Hou, G.; Chen, T.; Ma, K.; Liao, Z.; Xia, H.; Yao, T. Improving Social Acceptance of Waste-to-Energy Incinerators in China: Role of Place Attachment, Trust, and Fairness. Sustainability 2019, 11, 1727. [CrossRef] 